\section{Comment on}

\section{Lee M. Silver's article 'Reprogenetics: third millenium speculation' in EMBO reports, November 2000}

Lee Silver speculated in his viewpoint on the potential positive consequences of combining reproductive biology and genetics. Stating that, until recently 'the possibility that this technology might be applied to human embryos was not given serious consideration', he cited three barriers to the application of germ-line genetic engineering in humans. The first is the inefficiency of the technology and the second, the high risk of newly induced mutations. Finally, he evoked the potential constraint that 'genetic engineering can never be performed on people because of the possibility that a particular modification might have unanticipated negative side effects'. Optimistically, he went on to say that, 'all three problems can be overcome'. He overlooked, however, a further barrier to the use of human germ-line genetic engineering, a compelling and recurrent moral argument.

It is based on the conviction that civil society rests upon the respect for human beings as individuals, not as means to an end, and that ensuring the dignity of human beings is of capital importance. Germ-line gene therapy is, and always will be, intrinsically incompatible with these ideas. The Convention on Human Rights and Biomedicine (http://conventions.coe.int/ treaty/en/Treaties/Html/164.htm) states unambiguously in article 13, 'An intervention seeking to modify the human genome may only be undertaken for preventive, diagnostic or therapeutic purposes and only if its aim is not to introduce any modification in the genome of any descendants'. Similarly, the Council for Responsible Genetics has called for a permanent ban on germ-line gene modification (http://www.gene-watch.org/programs/
Position_Germline.html). And further, the 1999 resolution of the European Parliament (http://www.suepo.org/suepo/ resen.htm), issued in response to a patent relating to genetic manipulation of human cells and embryos, 'mistakenly' granted by the European Patent Office, states that the parliament was 'deeply shocked at the granting of a patent [...] which includes a technique for the genetic modification of the germ line of human embryos and of the embryos themselves'. Germ-line gene therapy has the potential to undermine civil society. This is why there are vigorous initiatives to oppose its application (http:// www.ciml.univ-mrs.fr/EWBANK_jonathan/ ELSI/GCindex.html), irrespective of any concerns about its safety or efficacy.

\section{Jonathan Ewbank}

Centre d'Immunologie de Marseille-Luminy, France DOI: 10.1093/embo-reports/kve060 